УДК $159.923: 616.895(02)$

https://doi.org/10.52058/2708-7530-2021-10(16)-412-422

Романенко Свген Олександрович доктор наук з державного управління, професор, Заслужений юрист України, Президент Всеукраїнської асамблеї докторів наук 3 державного управління, Проректор 3 наукової роботи, Національний авіаційний університет, проспект Любомира Гузара, 1, м. Київ, 03058, тел.: (063) 951-78-55, e-mail: poboss1978@gmail.com, https://orcid.org/00000003-2285-0543

Помиткіна Любов Віталіївна доктор психологічних наук, професор, завідувач кафедри авіаційної психології, Національний авіаційний університет, проспект Любомира Гузара, 1, м. Київ, 03058, тел.: (099) 138-4738, e-mail: Lyubvit@ukr.net, https://orcid.org/0000-0002-2148-9728

Бессонова Лілія Едуардівна старший лаборант психофізіологічної лабораторії кафедри авіаційної психології, Національний авіаційний університет, проспект Любомира Гузара, 1, м. Київ, 03058, тел.: (063) 075-79-25, e-mail: Tour.icecream@gmail.com, https://orcid.org/0000-0003-1592-0996

\title{
ОСОБЛИВОСТІ ПСИХОЛОГІЧНОЇ РЕАБІЛІТАЦІЇ УЧАСНИКІВ ООС ЯК СКЛАДОВА ДЕРЖАВНОЇ ПОЛІТИКИ
}

Анотація. Психологічна реабілітація подолання ПТСР ветеранів операції об'єднаних сил (ООС) є надзвичайно актуальною темою, особливо в період пандемії, коли створені обставини ізоляції посилюють наслідки отриманих психотравм. Метою статті було визначення пріоритетних напрямів психологічної реабілітації ветеранів учасників операції об'єднаних сил та висвітлення особливостей ефективної допомоги постраждалим від посттравматичних розладів. Проаналізовані сучасні праці зарубіжних та вітчизняних психологів, які з різних сторін висвітлюють особливості виникнення посттравматичних розладів, специфіку прояву у осіб, що отримали психотравмуючий вплив, класифікують види й методи психологічної та психотерапевтичної допомоги. Узагальнені й визначені основні кроки (1-5 кроків), що можуть забезпечити постраждалим ефективну допомогу в напрямі одужання. Особливу увагу приділено психотерапевтичним методам в руслі позитивної психотерапії та когнітивноповедінкової терапії, напрацюванням практиків щодо надання допомоги в напрямі розвитку оптимізму та залучення до здорового способу життя, а також технікам самодопомоги. Констатовано, що першочерговим завданням осіб, як постраждалих, так і тих хто має відношення до них, $\epsilon$ завчасне, постійне усвідомлення необхідності набуття знань та вмінь щодо засобів самодопомоги, 
саморегуляції та самовідновлення фізичного й психічного здоров'я, яке можна втратити, виконуючи обов'язки захисника держави. У висновку наголошено на необхідності створення осередків психолого-профілактичних інформаційнорозвивальних заходів для широкого кола майбутніх учасників військових дій, що збереже їх фізичне й психічне здоров'я та зміцнить національну безпеку нашої країни.

Ключові слова: ветерани, військові, національна безпека, постстресові розлади, психологічна реабілітація, психотерапія, профілактика, самодопомога.

Romanenko Yevhen Oleksandrovych Doctor of Science in Public Administration, Professor, Honored Lawyer of Ukraine, President of the Ukrainian Assembly of Doctors of Science in public administration, Vice-Rector for Research, National Aviation University, 1 Lubomyr Husar Ave., Kyiv, 03058, tel .: (063) 951-78-55, e-mail: poboss1978@gmail.com, https://orcid.org/0000-0003 -2285-0543

Pomytkina Liubov Vitaliyivna Doctor of Psychological Sciences, Professor, Head of the Department of Aviation Psychology, National Aviation University, 1 Lyubomyr Husar Ave., Kyiv, 03058, tel.: (099) 138-4738, e-mail: Lyubvit@ukr.net, https://orcid.org/0000-0002-2148-9728

Bessonova Liliia Eduardivna senior laboratory assistant of the psychophysiological laboratory of the Department of Aviation Psychology, National Aviation University, 1 Lyubomyr Husar Ave., Kyiv, 03058, tel.: (063) 075-79-25, e-mail: Tour.icecream@gmail.com, https://orcid.org/0000-0003-1592-0996

\title{
PECULIARITIES OF PSYCHOLOGICAL REHABILITATION OF JFO PARTICIPANTS AS A COMPONENT OF STATE POLICY
}

\begin{abstract}
Psychological rehabilitation of overcoming PTSD of veterans of the Joint Forces Operation (JFO) is an extremely relevant topic, especially during a pandemic, when the circumstances of isolation aggravate consequences of the received psychotraumas. The purpose of the article was to determine the priority areas of psychological rehabilitation of veterans of the joint forces operation and to highlight the features of effective care for victims of post-traumatic disorders. The modern works of foreign and domestic psychologists are analyzed, which from different angles highlight the features of occurrence of post-traumatic disorders, the specifics of manifestation in persons who have received psychotraumatic effects, classify the types and methods of psychological and psychotherapeutic care. The main steps (1-5 steps) that can provide victims with effective assistance in the direction of recovery are generalized and defined. Particular attention is paid to psychotherapeutic methods in line with positive psychotherapy and cognitive-behavioral therapy, the works of practitioners to help in the development of optimism and involvement in a healthy lifestyle, as well as self-help
\end{abstract}

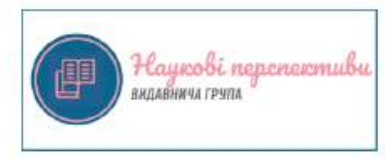


techniques. It is stated that the primary task of persons, both victims and those related to them, is early, constant awareness of the need to acquire knowledge and skills on self-help, self-regulation and self-restoration of physical and mental health, which can be lost by fulfilling obligations of the defender of the state. The conclusion emphasizes the need to create centers of psychological and preventive information and development activities for a wide range of future participants in hostilities, which will preserve their physical and mental health and strengthen the national security of our country.

Keywords: veterans, military, national security, post-stress disorders, psychological rehabilitation, psychotherapy, prevention, self-help.

Постановка проблеми. Політика кожної країни залежить від психіки конкретних людей. Усі форми відображення політики у психіці людей опосередковуються їх діяльністю, умовами життя, особистими життєвими цілями й прагненнями, фізичним і психічним здоров'ям. Якщо в країні відбуваються військові дії чи операції, це безумовно призводить до збільшення осіб, які різною мірою переживають так звані «постстресові розлади» (ПТСР), і які потребують психотерапевтичного втручання.

Надання психологічної допомоги особам після бойових дій не нове у світовій практиці. На базі сотень досліджень у літературі $\epsilon$ конкретні рекомендації стосовно психотерапевтичної та фармакологічної допомоги ветеранам війни. Наприклад, відділом у справах ветеранів та Міністерства оборони США розроблені науково обгрунтовані протоколи надання психотерапевтичної та фармакологічної допомоги на різних етапах: від запобігання травмам до складних і хронічних виявів посттравматичних розладів зі стійкими симптомами. Після війни США в Афганістані та Іраку перша загальна рекомендація полягала в тому, щоб тримати всю сім'ю у фокусі терапії i проводити терапію родини як цілісної системи. Досліджено, що кожний член сім'ї ветерана війни переживає дистрес, оскільки близька людина може не повернутись 3 війни чи 3 бойового завдання, або повернутися зміненою психологічно чи фізично.

Метою статті $\epsilon$ визначення пріоритетних напрямів психологічної реабілітації ветеранів учасників операції об'єднаних сил та висвітлення особливостей ефективної допомоги постраждалим від посттравматичних розладів.

Виклад основного матеріалу. Психологічна реабілітація подолання ПТСР ветеранів операції об'єднаних сил (ООС) є надзвичайно актуальною темою, особливо в період пандемії, коли створені обставини ізоляції посилюють наслідки отриманих психотравм. Вже 7 років на території держави тривають бойові дії. За статистичними даними, Україна посідає перше місце у Європі за поширенням психічних розладів, а хронічний стрес, невизначеність та нові умови буття під час пандемії сприяють погіршенню психічного здоров'я ветеранів, що 
призводить до формування посттравматичного синдрому. Цей негативний прояв відображається системно на всіх сферах буття України і на економічній, зокрема.

На думку експертів Всесвітньої організації охорони здоров'я, психічні розлади та розлади поведінки слід вважати однією з серйозних загроз здоров'ю та продуктивності нації. При цьому депресія та суїциди, розлади особистості, алкоголізм та наркоманія зберігають високу питому вагу в структурі психічних захворювань. Демобілізований ветеран, що страждає ПТСР, за можливість відчуття полегшення може стати причиною терористичної загрози або розголошення військової таємниці, тим самим представляючи потенційну небезпеку для країни.

Так, події в зоні проведення операції об’єднаних сил на території Донецької та Луганської областей обумовили необхідність оголошення мобілізації для збільшення чисельності Збройних Сил України. За повідомленням ЗМІ за всі шість хвиль мобілізації лави ЗСУ поповнили 210 тисяч військовослужбовців. Тому в армійському середовищі продовжує зростати кількість правопорушень, пов'язаних із проблемами психічних розладів. Протягом останніх трьох років спостерігається різке збільшення кількості кримінальних проваджень, пов'язаних з наслідками посттравматичних розладів військовослужбовців.

Дослідники зазначають, що посттравматичний стрес - це нормальна реакція людського організму на важкі травмуючі події. Але, якщо його не лікувати може перетворитися на дуже серйозне захворювання.

Дослідженням психологічного стану осіб, що перебували в зоні військових дій, а також осіб, страждаючих ПТСР від інших травмуючи подій, займалися вчені й дослідники як зарубіжні (Seidman, G., Shrout, Patrick, E., \& Bolger, N., 2006; Frewen P., Lanius R., 2014) так і вітчизняні (Дзеружинска Н., Сиропятов О., 2016; Голощапов А., 2016; Блінов О., 2019; Литвинчук Л., 2020 та ін.). Дослідники вважають ПТСР психічним розладом, який розвивається у людей, що перенесли травматичну подію у їх житті. Як вважається, більшість людей, що пережили травму, 3 часом відчувають поступове зменшення симптомів i відновлюються після впливу травми, однак, у деяких 3 них розвивається посттравматичний стресовий розлад і проявляються стійкі симптоми. Ця недуга піддається медикаментозно-терапевтичному лікуванню, але на перших стадіях іiі може допомогти позбутися психотерапевт.

Заслуговують на увагу дослідження сучасних науковців-психологів (Блінов О., 2019; Литвинчук, Л.,2020; Дзеружинска Н., Сиропятов О., 2014). Так дослідження О.А.Блінова дали можливість отримати новітні дані про особливості прояву бойового стресу у різних категорій військовослужбовців, легко- та важкопоранених, 3 внутрішньочерепною травмою: струсом головного мозку (контузією). На основі факторного аналізу було встановлено психологічну структуру переживань бойового стресу взагалі та переживання бойового стресу зокрема в учасників бойових дій. Також автор визначає ефективність надання психологічної допомоги військовослужбовцям після повернення із зони бойових

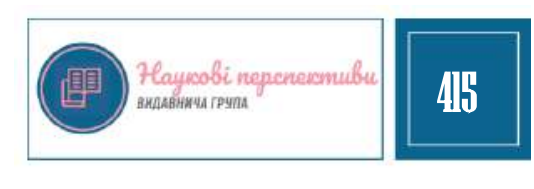


дій [1].

Психологічну характеристику мовленнєвих висловлювань як проблемної субстанції контролю дезадаптованих осіб здійснили науковці (Литвинчук Л., 2020), які зазначають, що проблеми психічного здоров'я мають велике значення для будь-якого суспільства і $є$ вагомим фактором збільшення захворюваності, зниження якості життя, що, у свою чергу, призводить до величезних економічних витрат і соціальних втрат. Напрям їх дослідження пов'язаний як 3 пошуком для загальних закономірностей розвитку та умов щодо ефективного впровадження процесу лікування, а також поведінки постраждалого, оскільки це важливий показник можливого прогнозу результатів реабілітації [6].

Дослідники (Дзеружинська Н., Сиропятов О., 2014) провели ряд досліджень посттравматичних розладів і розробили систему реабілітації військовослужбовців 3 бойовою психічною травмою, що дало змогу підготувати посібник для самопідготовки та самодопомоги під час переживання психотравми. Автори переконані, що свідома робота над собою також $є$ важливим кроком до одужання [4].

Заслуговують на увагу дослідження сучасних практиків (Гаранян Н., 2013; Голощапов А., 2016; Кошова С.П., Гбур 3.В., 2021), які зазначають, що довготривалий стрес призводить до виникнення психосоматичних хвороб. Стрес викликає термінову мобілізацію всіх компонентів системи крові для реалізації адаптивної реакції організму на стрес, і перш за все для активації імунної системи. Таким чином, при дії більш сильних стрес-реакцій відбувається пригнічення імунної системи i виявляється значне зниження активності нормальних «кілерів» - компонентів крові, зниження вмісту імуноглобулінів в крові і рівня нормальних протимікробних антитіл. Це супроводжується втратою здатності до формування повноцінної імунної відповіді, звуженням адаптаційних можливостей організму, порушенням оптимального співвідношення генетичної програми [5]. Отже на фоні ПТСР у постраждалого можуть виникнути ще й психосоматичні розлади.

Як відомо, основна мета психотерапії - допомогти клієнтові пройти через важкі часи, знайти ресурси і опору, які допоможуть йому адаптуватися до подій i знову приймати самостійні рішення, будувати життя далі [10].

Першим терапевтичним впливом може являтися сім'я постраждалого: як прийняли, як ставляться до певних проявів, як підтримують чи нехтують тощо. Якщо сім'ю спіткав такий розлад близької людини, доводиться міняти структуру сім'ї, а іноді й спосіб життя. Якщо, наприклад, мова йде про захворювання людини, яка заробляла гроші для сім’і, або вирішувала питання виховання дітей, то всій родині доводиться пройти через перебудову життя, i тут психотерапевтична підтримка буває дуже важлива. Стресові ситуації завжди пов'язані з втратою сенсу життя і дуже важливо, щоб людина знайшла цей сенс, знайшла на кого чи на що спертися, щоб рухатися далі.

Завдання психотерапії в тому, щоб людина, переживши травмуючі події, 
змогла жити далі повноцінним життям, наповненим сенсом і радістю. Багато людей, які зіткнулися з загрозливими для життя ситуаціями, бояться звертатися до психотерапевта, тому що побоюються, що їм доведеться знову переживати хворобливі моменти. Сучасна психотерапія захищає людину від повторного переживання травми. Психолог і психотерапевт, який спеціалізується на роботі 3 травмою, знає як вести процес психотерапії так, щоб він не був болючим $\mathrm{i}$ травматичним для пацієнта.

Аналіз науково-практичної психологічної літератури та практика спілкування 3 особами, що повернулися після ООС показує, що у значного відсотка учасників бойових дій, незалежно від того, отримали вони поранення, чи ні, спостерігається посттравматичний стресовий розлад.

Із розмов з клієнтами та родичами можемо відтворити основні симптоми, що повторюються:

- нав'язливі неприємні спогади;

- тривожні сни (наприклад, нічні кошмари) на тему події;

- неприємні відчуття ніби подія відбувається знову до повної втрати усвідомлення навколишньої дійсності;

- інтенсивний психологічний або фізіологічний дискомфорт при нагадуванні про травматичному подію (звуки, схожі на ті, що клієнт чув під час події, або видіння тощо);

- прояви страху, гніву, розпачу, різкі перепади настрою;

- деякі розлади пам'яті, особливо втрата зв'язку між датами і подіями;

- уникнення дій, місць, розмов або людей, які викликають спогади про подію;

- постійні негативні думки аж до втрати сенсу життя тощо.

Зрозуміло, що перебування у такому стані призводить до негативних наслідків для когнітивної здатності і настрою людини. Це може віддаляти сім'янина від інших членів сім'ї. А почуття відчуженості іще більше загострює травму. Крім того, такі прояви можуть викликати суттєвий дискомфорт або значно ускладнювати соціальну та професійну діяльність.

Для лікування посттравматичного стресового розладу успішно використовується широкий спектр психотерапевтичних методів. Аналіз літератури з медичної психології показує, що сучасні науковці й дослідники застосовують широкий спектр методів допомоги, серед яких вирізняється позитивна психотерапія Н. Пезешкіана, яка успішно протистоїть негативізму й депресії особистості. Власне, Н. Пезешкіан визначав цей метод як гуманістичний, глибинно психологічно орієнтований метод психотерапії 3 транскультуральної точки зору, з новими техніками в руслі клієнт центрованої і орієнтованої на ресурси людини короткострокової психотерапії.

Позитивний погляд на життя відроджується також виробленням оптимізму, який на відміну від песимізму, дає людині можливість сфокусуватися на позитивній стороні буття, на вмінні знаходити позитивні аспекти реальності навіть там, де негативних моментів більше. Дослідження вчених (Чернобровкіна

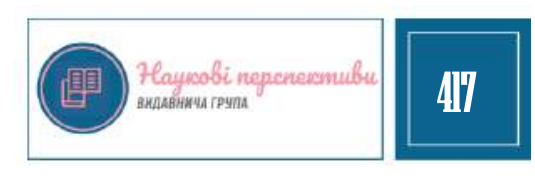


B., 2012) свідчать, що домінування позитивного ставлення до життя корелює 3 більш високими успіхами в просуванні до одужання, натомість песимізм пов'язаний з депресивністю [9].

До ефективних методів також відносять когнітивну поведінкову терапію (КПТ), яка допомагає навчитися по-іншому думати і реагувати на лякаючі події, які є поштовхом до розвитку ПТСР, і може допомогти взяти симптоми хвороби під контроль. Існує кілька типів когнітивно-поведінкової терапії, під час якої часто використовують ментальні образи, записи або відвідування місця пережитої травми, щоб допомогти постраждалим поглянути в обличчя їх страху i взяти його під контроль. Деякі психотерапевти радять використовувати реструктуризацію поведінки (когнітивна реструктуризація), яка спонукає пережити важку подію, висловлювати гнітючі (часто помилкові) думки про пережиту травму, оскаржувати ці думки і замінювати їх на більш збалансовані i конструктивні. Такі повернення в стресову ситуацію - вчать способам зменшення тривоги і вмінню з нею справлятися, допомагаючи послабити симптоми ПТСР, $\mathrm{i}$ коригувати помилковий хід думок, пов'язаних 3 пережитою травмою.

На нашу думку, на перших стадіях ПТСР необхідно звернутися до психологів та психотерапевтів, і лише вразі негативного досвіду, потім вдаватися до медикаментозного втручання. Тому радимо декілька кроків.

Крок 1. Індивідуальні зустрічі 3 психотерапевтом, який допоможе класифікувати ступінь розладу й обере найефективніший психотерапевтичний напрям та складе модель ефективної допомоги. Однак, оскільки необхідно клієнта вивести на самодопомогу, то пропонуємо крок 2.

Крок 2. Постійна самодопомога, заснована на підвищенні свідомості щодо необхідності об'єднання тренування фізичного тіла, що передбачає здоровий спосіб життя й є дієвим кроком до одужання, а також постійну роботу над розвитком самосвідомості, що може включати позитивні настрої, смислові аутотренінги, методи самопізнання й саморозвитку, емоційну саморегуляцію тощо $[3,4]$.

Крок 3. Постійна позитивна емоційна підтримка членами сім’ї. Повне безкорисне прийняття ветерана із його пораненим тілом чи душею, помірна опіка, участь в обговореннях нав'язливих спогадів, емпатія та співчуття, розуміння й терпіння, повна віра в одужання й налагодження сімейного життя. Досвідчені психологи свідчать, що процес пригнічення власних емоцій виснажує психічну енергію, знижує життєстійкість особистості, здатність бути щасливим. Ще давній філософ Спіноза звернув увагу на те, що емоції «...збільшують або зменшують здатність самого тіла до дії». Саме позитивні емоції спонукають людину до діяльності й досягнення корисного результату [5, с. 135].

Крок 4. Також не можна відкидати застосування каніс- і фелінотерапії під час страждання розладами ПТСР, про що зазначається в публікаціях дослідників (Романенко Є., Помиткіна Л., 2021). Коли мова йде про ефект зоотерапії, то мається на увазі насамперед ефект позитивного здоров’я, який проявляється 
через активну взаємодію з твариною і прийняття на себе відповідальності за турботу про неї. Це призводить нестільки до припинення болю (тілесного чи душевного), а до вироблення пристосувальних механізмів, необхідних для того, щоб бути успішним і долати труднощі.

Як зазначають автори, головна думка і ідея полягає в тому, що людина завжди залишається людиною, сильною і здатною жити, дбати про себе і про близьких. Прийняття відповідальності - «лікує і виховує». Отже, задоволення базових потреб надає можливості для зростання - внутрішнє напруження, що виникає при актуалізації потреб, призводить до виникнення і прояву активності. Задоволення дефіцітарних потреб і потреб зростання здійснює різний об'єктивний і суб'єктивний вплив на особистість. Задоволення дефіциту дозволяє уникнути хвороби, задоволення потреб зростання формує позитивне здоров'я [7, с. 145].

Крок 5. Звернення до лікарів 3 подальшим використанням медикаментозного лікування. До цього кроку мають перейти ті страждаючі ПТСР, яким не вдалося одужати під час перших чотирьох кроків. Це може бути пов'язано $з$ пролонгованою дією симптомів ПТСР, коли шанси на швидке одужання втрачені, та у випадках, коли недостатньо була отримана допомога, описана в перших чотирьох кроках. Можемо підкреслити важливість своєчасно розпочатої допомоги постраждалому як самостійної так i від найближчого оточення. Це безпосередньо вплине на швидкість та ефективність одужання від посттравматичних розладів.

Зазвичай, вибір типу психотерапії повинен здійснюватися 3 урахуванням потреб клієнта, а також його можливостей і переваг. Необхідно також взяти до уваги потенційні труднощі і побічні ефекти під час психотерапевтичної сесії, оскільки люди, які пережили психологічні травми, часто страждають від постійного нервового напруження. Це може викликати стан зверх пильності, дратівливість, проблеми зі сном, що в свою чергу призводить до стомлюваності і підсилює тривожно-депресивні симптоми. В цьому випадку терапія на рівні свідомості недостатня, і корисними можуть виявитися техніки релаксації. Ці техніки не тільки покращують стан клієнта, але і дозволяють йому подолати відчуття безпорадності 3 приводу своїх симптомів: він усвідомлює, що він здатний впоратися зі своїм тривожним станом.

У психологічній літературі досить широко представлені релаксаційні техніки, такі як м’язові, дихальні, медитативного характеру, або з використанням візуалізації. Використання технік релаксації корисно також на початку сеансу психотерапії. Вони дозволяють клієнтові легше переносити неприємні думки i емоції (страх, печаль, почуття безпорадності), не вдаючись до їх витіснення. Завдяки цьому людина легше усвідомлює свої тривожні думки і свій емоційний стан і може працювати над ними під час психотерапевтичного сеансу.

Необхідно також звернути увагу на ряд практичних порад, які на сьогодні пропонують сучасні психологи й психотерапевти. Цю практику публікують як зарубіжні так і вітчизняні дослідники. Зокрема, книга (Серван-Шрейбер, Д., 2013)

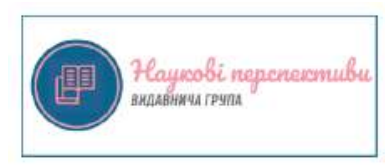


пропонує змінити спосіб життя i якщо слідувати їх методикам, то можна випрацювати антистрес і перемогти стресс, тревогу і депресію без ліків і навіть без психоаналізу. Об’єднавши свій лікувальний i дослідницький досвід, всесвітньо відомий нейробіолог Девід Серван-Шрейбер розробив виключно ефективні методи, які можуть допомогти налагодити взаємодію 3 емоційним мозком без лікарів і психотерапії. Оптимізація сердечного ритму, десенсибілізація за допомогою вправ для очей, синхронізація біологічних ритмів, акупунктура, правильне харчування, регулярні фізичні вправи та техніка «афективної комунікації» - це сім методів, запропонованих автором, які, на його думку, дозволяють керувати власним життям [8].

Серед вітчизняних дослідників вирізняється книга (Голощапов А., 2016) «Тривога, страх i панічні атаки», яка презентована широкому колу читачів i позиціонується як книга самодопомоги. Автор подав систему методів самодопомоги для постраждалих від ПТСР i конкретні техніки для само опрацювання, які можуть допомогти зняти стрес, позбавити від необгрунтованого гніву, нав’язливих страхів, покарщують якість сну та відпочинку [3].

Отже, поданий теоретичний аналіз засвідчує необхідність розробки й впровадження профілактичних та інформаційно-розвивальних заходів для широкого кола осіб до того, як вони потраплять у зону військових дій. Це можна здійснювати у ряді закладів з військовою підготовкою для студентської молоді, у рядах військової служби для новоприбулих осіб тощо, які ще в період навчання чи підготовки можуть опанувати різні техніки самодопомоги під час травмуючих обставин. Відповідно до національної політики, впроваджені заходи будуть дієвим способом запобіганню розвитку ПТСР в учасників ООС та ефективним підгрунтям щодо забезпечення національної безпеки нашої держави.

Таким чином, у результаті аналізу медико-психологічної літератури 3 проблем, пов'язаних 3 виникненням ПТСР, та сучасних методів подолання наслідків травмуючого впливу на особистість, приходимо до наступних висновків.

Висновки. Наша держава піклується про здоров'я й благополуччя своїх громадян, що зафіксовано у ряді законів, актів, розпоряджень різних Міністерств і в самій Конституції України. Однак, вважаємо, що й на сьогодні піклування про власне фізичне й психічне здоров'я залежить від самої особи та іï найближчого оточення. Однозначно із проведеного дослідження випливає, що сама людина, що страждає від ПТСР, самостійно, без підтримки щонайменше консультації психолога чи психотерапевта й членів родини, не зможе подолати хворобливі симптоми. Тому першочерговим завданням осіб, як постраждалих, так і тих хто має відношення до них, мають заздалегідь дбати про постійне усвідомлення необхідності набуття знань та вмінь засобів самодопомоги, саморегуляції та самовідновлення фізичного й психічного здоров'я, яке можна втратити, виконуючи обов'язки захисника держави. Створення осередків психологопрофілактичних інформаційно-розвивальних заходів для широкого кола 
майбутніх учасників військових дій збереже їх фізичне й психічне здоров'я та зміцнить національну безпеку нашої країни.

\section{Лimepamypa:}

1. $\quad$ Блінов О.А. Бойова психічна травма: монографія / О. А. Блінов; Ін-т психології ім. Г. С. Костюка НАПН України, Нац. авіац. ун-т. Київ: Талком, 2019. 699 с.

2. Гаранян Н.Г. Когнитивно-бихевиоральная психотерапия посттравматического стрессового расстройства // Консультативная психология и психотерапия. 2013. № 3. С. 46-72.

3. Голощапов А. Тревога, страх и панические атаки. Книга самопомощи. СПб.: ИГ «Весь», 2016. 176 с.

4. Дзеружинская Н.А., Сыропятов О.Г. Посттравматическое стрессовое расстройство. Пособие для самоподготовки. Киев: Украинская военно-медицинская академия, 2014.

5. Кошова С.П., Гбур 3.В. Особливості впливу негативних емоцій на розвиток психосоматичних захворювань людини / Наукові інновачії та передові технологіï. № 1(1) 2021. (Серія «Державне управління», Серія «Право», Серія «Економіка», Серія «Психологія», Серія «Педагогіка»). С.130-140. https://doi.org/10.52058/2786-5274 -2021-1(1)-130-140

6. Романенко С.О., Помиткіна Л.В. Обгрунтування та методика психокорекційної програми при симптомах посттравматичного стресового розладу із застосуванням каніс- i фелінотерапії / Наукові інновачіï та передові технологіï. № 1(1) 2021. (Серія «Державне управління», Серія «Право», Серія «Економіка», Серія «Психологія», Серія «Педагогіка»). C. 141-151. https://doi.org/10.52058/2786-5274-2021-1(1)-141-151

7. Серван-Шрейбер Д. Антистресс. Как победить стресс, тревогу и депрессию без лекарств и психоанализа / Д. Серван-Шрейбер ; [пер. с англ. Э. А. Болдиной]. М.: РИПОЛ классик, 2013. 352 с. (Новый образ жизни).

8. Чернобровкіна В.А. Психологія особистісної свободи: монографія / Віра Андріївна Чернобровкіна; Держ. закл. «Луган. нац. ун-т імені Тараса Шевченка». Луганськ: вид-во ДЗ «ЛНУ імені Тараса Шевченка», 2012. 458 с.

9. Lytvynchuk L., Pomytkina L. Psychological characteristics of speech utterances as a problem substing control maladjusted individuals. European science: scientific journal. Slovak Republik: European Institute of Further Education, Vol 1. No 4, 2020. P. 136-145.

http://www.eidv.eu/subory/publikacie/2019-europska-veda-11.pdf

10. L. Pomytkina, A. Gudmanian, O. Kovtun, S. Yahodzinskyi, Personal choice: strategic life decision-making and conscience. E3S Web of Conferences, Vol.164, 10021 (2020) https://doi.org/10.1051/e3sconf/202016410021

11. Seidman, G., Shrout, Patrick E., \& Bolger, N. (2006). Why is enacted social support associated with increased distress? Using simulation to test two possible sources of spurious-ness. Personality and Social Psychology Bulletin, 32, 52-65. doi:10.1177/014616720527958

12. Frewen P., Lanius R. Healing the Traumatized Self: Consciousness Neuroscience Treatment. WW Norton, 2014. 416 c.

\section{References:}

1. Blinov, O. A. (2019). Boiova psykhichna travma: monohrafiia [Combat mental trauma: a monograph] / O. A. Blinov; In-t psykholohii im. H. S. Kostiuka NAPN Ukrainy, Nats. aviats. un-t. Kyiv: Talkom [in Ukrainian].

2. Haranian, N. H. (2013). Kohnytyvno-bykhevyoralnaia psykhoterapyia posttravmatycheskoho stressovoho rasstroistva [Cognitive-behavioral psychotherapy of post-traumatic stress disorder] // Konsultatyvnaia psykholohyia y psykhoterapyia. № 3. S. 46-72 [in Russian].

3. Holoshchapov, A. Trevoha, strakh y panycheskye ataky. Knyha samopomoshchy [Anxiety, fear and panic attacks. Self-help book]. SPb.: YH «Ves», 2016. 176 s. [in Russian].

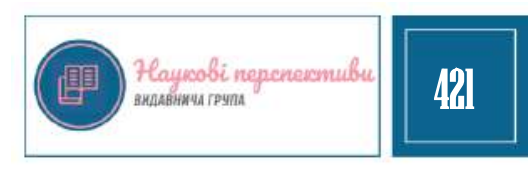


4. Dzeruzhynskaia, N.A., Suropiatov, O.H. (2014). Posttravmatycheskoe stressovoe rasstroistvo. Posobye dlia samopodhotovky [Post-traumatic stress disorder. Handbook for selfpreparation]. Kyev: Ukraynskaia voenno-medytsynskaia akademyia. [in Ukrainian].

5. Koshova, S.P., Hbur, Z.V. (2021). Osoblyvosti vplyvu nehatyvnykh emotsii na rozvytok psykhosomatychnykh zakhvoriuvan liudyny [Features of the influence of negative emotions on the development of human psychosomatic diseases] / Naukovi innovatsii ta peredovi tekhnolohii. № 1(1). (Seriia «Derzhavne upravlinnia», Seriia «Pravo», Seriia «Ekonomika», Seriia «Psykholohiia», Seriia «Pedahohika»). S.130-140 [in Ukrainian].

https://doi.org/10.52058/2786-5274 -2021-1(1)-130-140

6. Romanenko, Ye.O., Pomytkina, L.V. (2021). Obgruntuvannia ta metodyka psykhokorektsiinoi prohramy pry symptomakh posttravmatychnoho stresovoho rozladu iz zastosuvanniam kanis- $\mathrm{i}$ felinoterapii [Rationale and methods of psychocorrection program for symptoms of post-traumatic stress disorder with the use of canis and feline therapy] / Naukovi innovatsii ta peredovi tekhnolohii. № 1(1). (Seriia «Derzhavne upravlinnia», Seriia «Pravo», Seriia «Ekonomika», Seriia «Psykholohiia», Seriia «Pedahohika»). S. 141-151 [in Ukrainian].

https://doi.org/10.52058/2786-5274-2021-1(1)-141-151

7. Servan-Shreiber, D. (2013). Antystress. Kak pobedyt stress, trevohu y depressyiu bez lekarstv y psykhoanalyza [Anti-stress. How to overcome stress, anxiety and depression without medication and psychoanalysis] / D. Servan-Shreiber; [per. s anhl. Э. A. Boldynoi]. M.: RYPOL klassyk. 352 s. (Noviy obraz zhyzny) [in Russian].

8. Chernobrovkina, V.A. (2012). Psykholohiia osobystisnoi svobody: monohrafiia [Psychology of personal freedom: a monograph] / Vira Andriivna Chernobrovkina; Derzh. zakl. «Luhan. nats. un-t imeni Tarasa Shevchenka». Luhansk: vyd-vo DZ «LNU imeni Tarasa Shevchenka». 458 s. [in Ukrainian].

9. Lytvynchuk, L., Pomytkina, L. (2020). Psychological characteristics of speech utterances as a problem substing control maladjusted individuals. European science: scientific journal. Slovak Republik: European Institute of Further Education, Vol 1. No 4. P. 136-145. [in Slovak Republik].

http://www.eidv.eu/subory/publikacie/2019-europska-veda-11.pdf

10. L. Pomytkina, A. Gudmanian, O. Kovtun, S. Yahodzinskyi (2020). Personal choice: strategic life decision-making and conscience. E3S Web of Conferences, Vol.164, 10021 [in Russian].

https://doi.org/10.1051/e3sconf/202016410021

11. Seidman, G., Shrout, Patrick E., \& Bolger, N. (2006). Why is enacted social support associated with increased distress? Using simulation to test two possible sources of spurious-ness. Personality and Social Psychology Bulletin, 32, 52-65. doi:10.1177/014616720527958 [in USA].

12. Frewen, P., Lanius, R. (2014). Healing the Traumatized Self: Consciousness Neuroscience Treatment. WW Norton. 416 p. [in London]. 